\title{
Analisis Pengaruh Pendidikan Dan Pelatihan, Motivasi Dan Kompensasi Terhadap Kinerja Karyawan (Pada Citibank Pondok Indah Jakarta Selatan)
}

\author{
Retno Japanis Permatasari \\ Dosen Fakultas Ekonomi Universitas Pamulang \\ Email: dosen01337@unpam.ac.id
}

\begin{abstract}
ABSTRAK
Tujuan dari penelitian ini adalah untuk mengetahui pendidikan dan pelatihan berpengaruh terhadap kinerja di Citibank Pondok Indah Jakarta Selatan, mengetahui motivasi berpengaruh terhadap kinerja karyawan di Citibank Pondok Indah Jakarta Selatan, mengetahui kompensasi berpengaruh terhadap kinerja karyawan di Citibank Pondok Indah Jakarta Selatan dan mengetahui seberapa besar pengaruh pendidikan dan pelatihan, motivasi dan kompensasi terhadap kinerja karyawan pada Citibank Pondok Indah Jakarta Selatan.

Dalam penelitian tesis ini, penulis menggunakan metode penelitian yang digunakan menggunakan metode Survei Eksplanatori/eksplanatif/deskriftif korelasional yang bersifat meneliti hubungan antara variabel-variabel yang diteliti, sehingga akan diketahui seberapa besar pengaruh pendidikan dan pelatihan dan motivasi berpengaruh secara bersama-sama terhadap kinerja karyawan di lingkungan Citibank Pondok Indah Jakarta Selatan. Populasi target dalam penelitian ini adalah seluruh pegawai bagian penagihan (deskcollection) Citibank yang berjumlah 150 karyawan, sedangkan sampel dengan menggunakan rumus slovin taraf signifikan 5\% diperoleh sampel sebanyak 110 responden.

Hasil pengujian secara parsial diperoleh nilai t hitung > t tabel $(5.305>$ 1.98) adalah Ho ditolak dan Ha diterima hal ini berarti variabel Pendidikan dan Pelatihan $\left(\mathrm{X}_{1}\right)$ berpengaruh signifikan terhadap variabel Kinerja Karyawan $(\mathrm{Y})$. Sedangkan nilai $\mathrm{t}$ hitung $>\mathrm{t}$ tabel $(9.913>1.98)$ adalah Ho ditolak dan $\mathrm{Ha}$ diterima hal ini berarti variabel Motivasi $\left(\mathrm{X}_{2}\right)$ berpengaruh signifikan terhadap variabel Kinerja Karyawan (Y). Sedangkan nilai t hitung > t tabel $(2.610>1.98)$ adalah Ho ditolak dan Ha diterima hal ini berarti variabel Kompensasi $\left(\mathrm{X}_{3}\right)$ berpengaruh signifikan terhadap variabel Kinerja Karyawan (Y). Secara simultan nilai $\mathrm{F}$ hitung $>\mathrm{F}$ tabel $(42.716>2.69)$ adalah Ho ditolak dan Ha diterima, berarti bahwa Pendidikan dan Pelatihan $\left(\mathrm{X}_{1}\right)$, Motivasi $\left(\mathrm{X}_{2}\right)$ dan Kompensasi $\left(\mathrm{X}_{3}\right)$ berpengaruh secara signifikan terhadap Kinerja Karyawan (Y) secara bersamasama (simultan).
\end{abstract}

Kata Kunci: Pendidikan dan Pelatihan, Motivasi, Kompensasi dan Kinerja. 


\section{PENDAHULUAN}

\section{Latar Belakang}

Citibank dalam pemberian pelatihan kepada karyawan masih dirasa belum maksimal karena training yang diberikan hanya bersifat online yaitu via komputer yang ada di tempat duduk kerja masing-masing mengisi beberapa pelatihan seperti service customer, money laundering, skill communication. Diharapkan Citibank dapat menciptakan pelatihan yang lebih inovatif sehingga para karyawan tidak jenuh training hanya membaca melalui layar monitor maupun hanya mendengarkan trainer bercerita dan menjelaskan tentang meningkatkan kinerja tanpa ada seperti pelatihan secara langsung (interaksi karyawan yang satu dengan yang lainnya). Hasilnya juga kurang efektif karena karyawan setelah training hanya sebatas mengisi pertanyaan kemudian pada waktu training berlangsung karyawan juga ada yang tertidur atau asyik bermain dengan handphone dan gadgetnya. Setelah karyawan mengikuti training barulah mendapatkan sertifikat.

Dalam hal pemberian kompensasi Citibank juga dirasa masih belum optimal karena status karyawan yang masih kontrak walaupun sudah lama bekerja lebih dari 3 tahun. Karyawan berharap ada kepastian tentang status jabatan seperti halnya ada pengangkatan karyawan tetap. Promosi jabatan yang diharapkan karyawan pada kenyataannya tidak ada. Karyawan yang sudah lama bekerja mencurahkan tenaga dan pikirannya ketika kontrak kerja berakhir maka karyawan tidak memperoleh pesangon atau tunjangan lainnya. Nah dari permasalahan itulah yang terkadang membuat motivasi yang ada dalam diri karyawan tersebut mengalami penurunan sehingga berdampak pula terhadap kinerja yang dihasilkan seperti karyawan tersebut tidak mencapai target sesuai yang diharapkan perusahaan. Kebanyakan karyawan yang bekerja di Citibank sudah 5 tahun mengabdi dan tetap menjadi karyawan kontrak sampai dengan sekarang khususnyadi bagian penagihan (desckcollection)

\section{Identifikasi Masalah}

Berdasarkan latar belakang masalah di atas dapat diidentifikasikan permasalahan penelitian yang berkaitan dengan pendidikan dan pelatihan, motivasi, kompensasi dan kinerja karyawan antara lain:

1. Kurangnya diklat untuk karyawan.

2. Instruktur/pengajar dalam diklat kurang mampu memberikan arahan dengan baik.

3. Tujuan diklat belum terlaksana dengan optimal.

4. Materi diklat belum memenuhi sasaran yang ingin dicapai.

5. Pemberian promosi jabatan kepada karyawan belum berjalan optimal.

6. Besarnya uang lembur yang diberikan kepada karyawan belum sesuai dengan kelebihan waktu kerja karyawan.

7. Kualitas kerja yang belum maksimal.

8. Hubungan kerja dengan rekan kerja belum berjalan dengan baik untuk meningkatkan kinerja.

9. Kurangnya motivasi kerja yang dimiliki karyawan. 
10. Belum optimalnya kinerja karyawan dalam hal pencapaian target.

\section{Pembatasan Masalah}

Mengingat berbagai keterbatasan kemampuan yang ada dan cukup banyaknya masalah yang diidentifikasi sehingga tidak mungkin semua masalah secara sekaligus dapat diteliti. Maka penulis, membatasi ruang lingkup penelitian, hanya difokuskan pada :

1. Pendidikan dan Pelatihan adalah pendidikan (formal) di dalam suatu organisasi adalah suatu prosespengembangan

kemampuan ke arah yang diinginkan oleh organisasi yang bersangkutan. Sedang pelatihan (training) adalah merupakan bagian dari suatu proses pendidikan, yang tujuannya untuk meningkatkan kemampuan atau keterampilan khusus seseorang atau kelompok orang. Penggunaan istilah pelatihan sering digunakan dengan istilah latihan atau "training". Latihan ialah salah satu cara untuk memperoleh keterampilan tertentu, misalnya latihan menari, latihan sepeda, latihan baris berbaris, dan sebagainya (Notoatmodjo, 2009:16).

2. Motivasi adalah pemberian daya penggerak yang menciptakan kegairahan kerja seseorang, agar mereka mau bekerja sama, bekerja efektif dan terintegerasi dengan segala daya upayanya untuk mencapai kepuasan (Sutrisno, 2009:111).
3. Kompensasi adalah imbalan atau penghargaan yang adil dan layak terhadap karyawan sesuai dengan kemampuan karyawan dalam melaksanakan pekerjaan dan segala sesuatu yang bermanfaat bagi perusahaan (Setiawan, 2012:35).

4. Kinerja Karyawan adalah suatu hasil kerja secara kualitas dan kuantitas yang dicapai oleh seorang pegawai dalam melaksanakan tugasnya sesuai dengan tanggung jawab yang diberikan kepadanya (Mangkunegara, 2000:67)

5. Lokasi penelitian di Citibank Pondok Indah Jakarta Selatan.

6. penelitian ini 3 bulan

\section{Perumusan Masalah}

Berdasarkan pada latar belakang dan identifikasi permasalahan di atas, dapat dirumuskan beberapa permasalahan pada penelitian sebagai berikut :

1. Seberapa besar pengaruh positif dan signifikan antara pendidikan dan pelatihan terhadap kinerja karyawan di Citibank?

2. Seberapa besar pengaruh positif dan signifikan antara motivasi terhadap kinerja karyawan di Citibank?

3. Seberapa besar pengaruh positif dan signifikan antara kompensasi terhadap kinerja karyawan di Citibank?

4. Seberapa besar pengaruh positif dan signifikan antara pendidikan 
dan pelatihan, motivasi dankompensasi terhadap kinerja karyawan di Citibank?

\section{Tujuan Penelitian}

Tujuan yang secara spesifik hendak dicapai dalam penelitian ini adalah sebagai berikut :

1. Untuk mengetahui seberapa besar pengaruh positif pendidikan dan pelatihan terhadap kinerja karyawan di Citibank.

2. Untuk mengetahui seberapa besar pengaruh positif motivasi terhadap kinerja karyawan di Citibank.

3. Untuk mengetahui seberapa besar pengaruh positif kompensasi terhadap kinerja karyawan di Citibank.

4. Untuk mengetahui seberapa besar pengaruh positif pendidikan dan pelatihan, motivasi dan kompensasi terhadap kinerja karyawan di Citibank.

\section{LANDASAN TEORI \\ Manajemen}

Manajemen telah banyak disebut sebagai "seni untuk menyelesaikan pekerjaan melalui orang lain". mengandung arti bahwa para manajer mencapai tujuan-tujuan organisasi melalui pengaturan orangorang lain untuk melaksanakan berbagai pekerjaan yang diperlukan, atau dengan kata lain dengan tidak melakukan pekerjaan-pekerjaan itu sendiri (Hani Handoko, 2010:3).

\section{Manajemen Sumber Daya Manusia}

Manajemen sumber daya manusia adalah ilmu dan seni mengatur hubungan dan peranan tenaga kerja agar efektif dan efisien membantu terwujudnya tujuan perusahaan, karyawan, dan masyarakat (Hasibuan, 2001:10).

\section{Pendidikan dan Pelatihan}

Pendidikan secara umum adalah segala upaya yang direncanakan untuk mempengaruhi orang lain baik individu, kelompok, atau masyarakat sehingga mereka melakukan apa yang diharapkan oleh pelaku pendidikan (Notoatmodjo, 2003 : 16).

Pengertian pelatihan adalah usaha untuk memperbaiki penguasaan berbagai keterampilan dan teknik pelaksanaan kerja tertentu, terinci dan rutin (Handoko, 2010:104).

\section{Motivasi}

Motivasi adalah pemberian daya penggerak yang menciptakan kegairahan kerja seseorang, agar mereka mau bekerja sama, bekerja efektif, dan terintegrasi dengan segala daya upayanya untuk mencapai kepuasan (Sutrisno, 2009:111).

\section{Kompensasi}

Kompensasi adalah semua bentuk penggajian atau ganjaran mengalir kepada pegawai dan timbul dari kepegawaiannya mereka (Yani, 2012:139).

5. Kinerja

Kinerja adalah hasil yang diperoleh oleh suatu organisasi baik organisasi tersebut bersifat profit oriented dan non profit oriented yang dihasilkan selama satu periode waktu. Secara lebih tegas kinerja merupakan hasil pekerjaan yang mempunyai hubungan kuat dengan tujuan strategis organisasi, kepuasan konsumen dan memberikan 
kontribusi ekonomi (Fahmi, 2010:2)

Kerangka Pemikiran

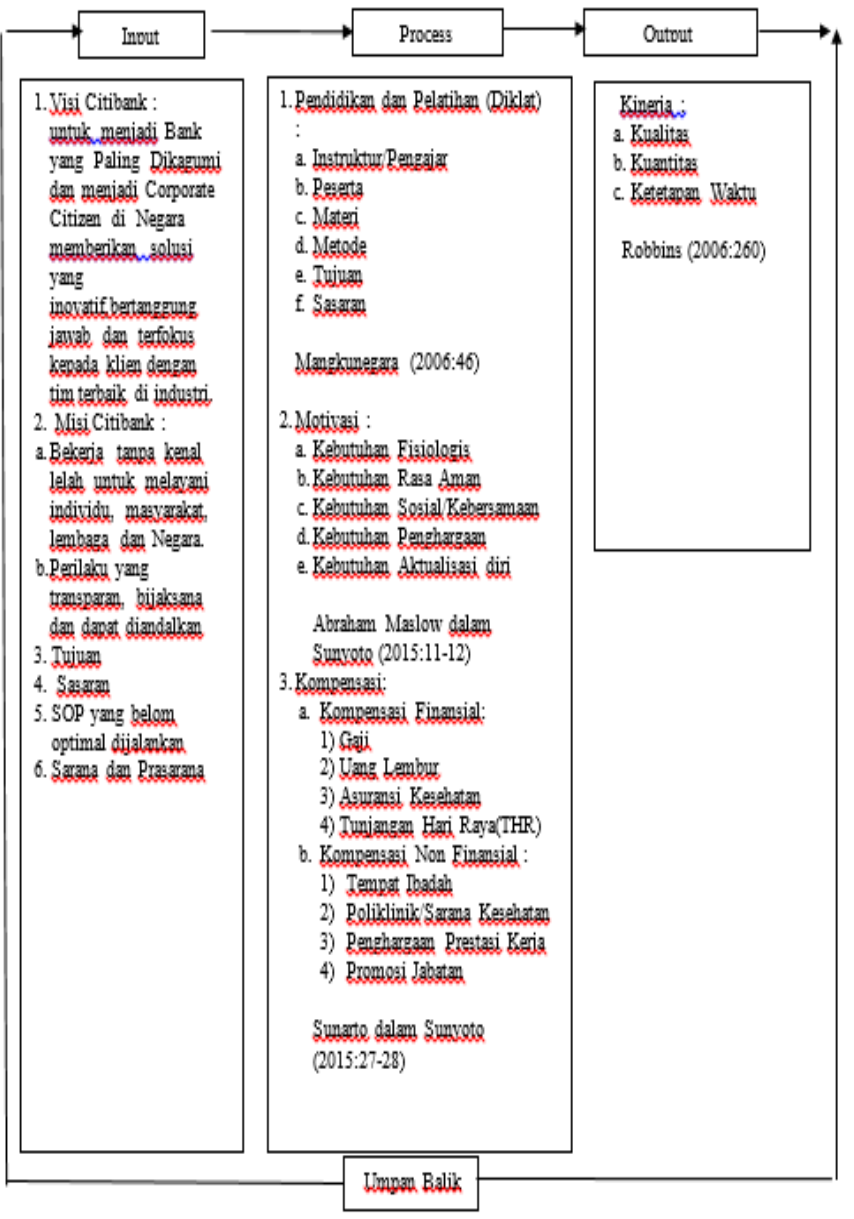

\section{Gambar 1.1 Kerangka Pemikiran}

\section{Hipotesis Penelitian}

$\mathrm{H} 1$ : diduga terdapat pengaruh positif dan signifikan antara pendidikan dan pelatihan terhadap kinerja karyawan di Citibank.

$\mathrm{H} 2$ : diduga terdapat pengaruh positif dan signifikan antara motivasi terhadap kinerja karyawan di Citibank.

$\mathrm{H} 3$ : diduga terdapat pengaruh positif dan signifikan antara kompensasi terhadap kinerja karyawan di Citibank.
$\mathrm{H} 4$ : diduga terdapat pengaruh positif dan signifikan antara pendidikan dan pelatihan, motivasi dan kompensasi terhadap kinerja karyawan di Citibank.

\section{Rancangan Analisis}

1. Rancangan Analisis

Analisis Kuantitatif, suatu bentuk analisis yang penyajiannya dalam angka-angka yang dapat diukur dan dihitung. Tingkat ukuran yang dipakai dalam pengukuran variabel adalah dengan skala Likert, dimana seorang responden dihadapkan pada beberapa pertanyaan kemudian diminta memberikan jawabannya. Hasil perhitungan dari skor atau nilai kemudian digunakan dalam analisis statistik yang dilakukan dengan bantuan komputer, menggunakan program SPSS untuk membuktikan hubungan dan pengaruh antara variabel-variabel penelitian dengan menggunakan uji data.

2. Uji Persyaratan Untuk Analisis Regresi

a. Uji Normalitas

Uji normalitas bertujuan menguji apakah model regresi, variabel bebas dan variabel terikat, keduanya terdistribusikan secara normal ataukah tidak. Dalam penelitian ini uji normalitas menggunakan

Kolmogorov-Smirnov SPSS, dengan kriterianya jika hasil uji perhitungan lebih besar dari 0,05 berarti data berdistribusi normal.

Uji normalitas data dalam penelitian ini juga dilihat dengan 
cara memperhatikan titik-titik pada Normal P-Plot of Regression Standardized Residual dari variabel terikat dengan kriterianya jika data menyebar di sekitar garis diagonal, maka model regresi memenuhi asumsi normalitas. Jika data menyebar jauh dari garis diagonal dan atau tidak mengikuti garis diagonal, maka model regresi tidak memenuhi asumsi normalitas.

b. Uji Multikolinieritas

Pengujian multikolinieritas bertujuan untuk mengetahui hubungan yang sempurna antar variabel bebas dalam model regresi. Gejala multikolinieritas dapat dilihat dari nilai tolerance dan nilai Varian Inflaction Factor (VIF). Bila nilai VIF lebih kecil dari 10 dan nilai toleransinya di atas 0,1 atau $10 \%$ maka dapat disimpulkan bahwa model regresi tersebut tidak terjadi multikolinieritas (Komala, 2014:65).

3. Uji Hipotesis

\section{a. Uji Korelasi}

Korelasi Pearson Product Moment (PPM) ini dikemukakan oleh Karl Pearson tahun 1900, kegunaannya utuk mengetahui derajat hubungan antara variabel bebas (independent) dengan variabel terikat (dependent). Teknik analisis Korelasi PPM termasuk teknik statistik parametrik yang menggunakan data interval dan ratio dengan persayaratan tertentu. Korelasi PPM dilambangkan (r) dengan ketentuan nilai $\mathrm{r}$ tidak lebih dari harga $(-1 \leq \mathrm{r} \leq+1)$. Apabila nilai $r=-1$ artinya korelasinya negatif sempurna; $r=0$ artinya tidak ada korelasi; dan $\mathrm{r}=1$ berarti korelasinya sangat kuat. (Riduwan dan Engkos, 2012:62)

Besarnya Koefisien Korelasi (r) antara dua variabel adalah untuk dapat memberi interpretasi terhadap kuat atau lemahnya pengaruh maka digunakan pedoman sebagai berikut :

Tabel 3.1

Pedoman Untuk Memberikan

Interpretasi Koefisien Korelasi

\begin{tabular}{|c|c|l|}
\hline No & $\begin{array}{c}\text { Interval } \\
\text { Koefisien }\end{array}$ & \multicolumn{1}{|c|}{ Tingkat Hubungan } \\
\hline 1 & $0,00-0,199$ & Sangat rendah \\
\hline 2 & $0,20-0,399$ & Rendah \\
\hline 3 & $0,40-0,599$ & Sedang \\
\hline 4 & $0,60-0,799$ & Kuat \\
\hline 5 & $0,80-1,000$ & Sangat kuat \\
\hline
\end{tabular}

Sumber : (Sugiyono, 2013:242)

Adapun rumus koefisien korelasi yang dipergunakan adalah sebagai berikut :

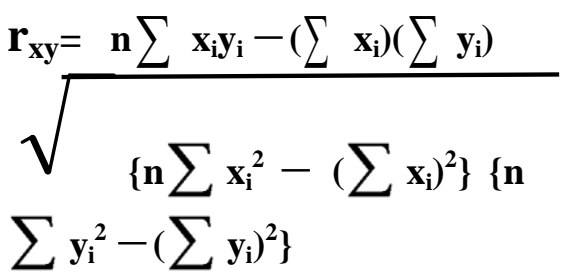

Keterangan :

$\mathrm{r}_{\mathrm{xy}} \quad: \quad$ Koefisien validitas item yang di cari n : Jumlah responden

$\sum \mathrm{x}_{\mathrm{i}}$ : Jumlah skor dalam variabel $\mathrm{x}$

$\sum \mathrm{y}_{\mathrm{i}}$ : Jumlah skor dalam variabel y

$\sum \mathrm{x}_{\mathrm{i}}{ }^{2}$ : Jumlah kuadrat masing-masing skor $\mathrm{x}$ 


$$
\begin{aligned}
& \sum \mathrm{y}_{\mathrm{i}}{ }^{2}: \text { Jumlah } \\
& \text { kuadrat } \\
& \text { skor } \mathrm{y} \\
& \sum \mathrm{x}_{\mathrm{i}} \mathrm{y}_{\mathrm{i}}: \text { Jusing-masing } \\
& \text { perkiraan }
\end{aligned}
$$

b. Uji Regresi Linier Berganda

Regresi linier berganda adalah regresi yang didalamnya terdapat satu variabel dependent (Y) dan lebih dari satu variabel independent (X). Variabel dependent adalah variabel terikat yang merupakan variabel yang dipengaruhi oleh variabel independent (bebas). Variabel dependent (terikat)dalam penelitian ini adalah kinerja. Sedangkan variabel independent (bebas) adalah pendidikan dan pelatihan, motivasi dan kompensasi. Penelitian ini menggunakan model regresi linier berganda dengan menggunakan program

\begin{tabular}{|c|c|}
\hline Y & : Kinerja \\
\hline & Konstanta \\
\hline $\begin{array}{l}\beta_{1}, \beta_{2}, \beta_{3} \\
\text { variabel indepen }\end{array}$ & $\begin{array}{l}\text { : Koefis } \\
\text { ndent }\end{array}$ \\
\hline $\begin{array}{l}X_{1} \\
\text { dan Pelatihan }\end{array}$ & . $\quad \mathrm{P}$ \\
\hline $\mathrm{X}_{2}$ & : Motivasi \\
\hline $\mathrm{X}_{3}$ & : Kompensa \\
\hline
\end{tabular}
SPSS yang dirumuskan sebagai berikut :

$$
\mathbf{Y}=\alpha+\beta_{1} \mathbf{X}_{1}+\beta_{2} \mathbf{X}_{2}+\beta_{3} \mathbf{X}_{3}
$$

Keterangan :

c. Uji Koefisien Determinasi

Untuk menyatakan besar kecilnya sumbangan variabel $\mathrm{X}$ terhadap $\mathrm{Y}$ dapat ditentukan dengan rumus koefisien determinan. Koefisien determinasi adalah kuadrat dari koefisien korelasi Pearson Product Moment (PPM) yang dikalikan dengan $100 \%$. Dilakukan untuk mengetahui seberapa besar variabel $\mathrm{X}$ mempunyai kontribusi atau ikut menentukan variabel $Y$. Derajat koefisien determinasi dicari dengan menggunakan rumus : (Riduwan dan Engkos, 2012:173)

$$
K P=r^{2} \times 100 \%
$$

Keterangan :

KP : Nilai Koefisien

Determinan

r : Nilai Koefisien Korelasi

d. Uji Regresi Secara Parsial (Uji t)

Uji t digunakan untuk mengetahui hubungan masing-masing variabel independent (bebas) secara individual terhadap variabel dependent (terikat). Untuk mengetahui ada tidaknya pengaruh masing-masing variabel independent (bebas) secara individual terhadap variabel dependent (terikat) digunakan tingkat signifikasi 5\% atau 0,05.

Jika probability t lebih besar dari 0,05 maka tidak ada pengaruh dari variabel independent (bebas) terhadap variabel dependent (koefisien regresi tidak signifikan), sedangkan jika nilai probability $\mathrm{t}$ lebih kecil dari 0,05 maka terdapat pengaruh dari variabel independent terhadap variabel dependent (koefisien signifikan). Dinyatakan dengan rumus : (Riduwan dan Engkos, 2012:167)

$$
\mathbf{t}_{\text {hitung }}=\frac{\mathbf{r} \sqrt{n}-2}{\sqrt{1}-\mathbf{r}^{2}}
$$


Keterangan :t $\quad$ : Nilai $\mathrm{t}_{\text {hitung }}$

$\mathrm{r} \quad$ : Koefisien korelasi hasil $\mathrm{r}$

hitung

n : Jumlah responden

e. Uji Signifikasi Simultan (Uji F) Uji statistik $F$ pada dasarnya menunjukkan apakah semua variabel independent (bebas) yang dimasukkan dalam model mempunyai pengaruh secara simultan (bersama-sama) terhadap variabel dependent (terikat) untuk mengambil keputusan hipotesis diterima atau ditolak dengan membandingkan tingkat signifikan sebesar 0,05.

Variabel-variabel independent (bebas) secara simultan (bersama-sama) mempengaruhi variabel dependent (terikat), dilakukan dengan membandingkan p-value pada kolom Sig(Harjoyo, 013:61). Dengan tingkat signifikasi yang digunakan sebesar 0,05. Jika $p$ value lebih kecil dari 0,05 maka Ha diterima dan Ho ditolak, sebaliknya jika $p$-value lebih besar dari 0,05 maka Ha ditolak dan Ho diterima.

Jika nilai probabilitas 0,05 lebih kecil atau sama dengan nilai probabilitas Sig atau $[0,05$ $\leq S i g]$, maka Ho diterima dan Ha ditolak, artinya tidak signifikan. Jika nilai probabilitas 0,05 lebih besar atau sama dengan nilai probabilitas Sig atau $[0,05$ $\geq$ Sig], maka Ho ditolak dan Ha diterima, artinya signifikan. Dinyatakan dengan rumus (Sugiyono, 2013:252) :

$$
F_{h i t}=\frac{R^{2} / k}{\left(1-R^{2}\right) /(n-k-1)}
$$

Keterangan :

$\mathrm{F}_{\text {hit }} \quad$ : Nilai hitung

R : Koefisien korelasi ganda

k : Jumlah variabel independent

$\mathrm{n} \quad$ : Jumlah anggota sampel

Berdasarkan hasil pengujian secara statistik dapat terlihat jelas bahwa secara parsial (individu) semua variabel bebas berpengaruh terhadap variabel terikat. Pengaruh yang diberikan ketiga variabel bebas tersebut bersifat positif artinya semakin tinggi pengaruh pendidikan dan pelatihan, motivasi dan kompensasi maka mengakibatkan semakin tinggi pula kinerja karyawan. Hasil tersebut sesuai dengan hipotesis yang diajukan.

Penjelasan dari masingmasing pengaruh variabel dijelaskan sebagai berikut :

1. Pengaruh Pendidikan dan Pelatihan terhadap Kinerja

Karyawan

Hasil pengujian pengaruh Pendidikan dan pelatihan terhadap kinerja karyawan secara statistik menunjukkan hasil yang positif dan signifikan. Hal itu ditunjukkan oleh nilai t hitung sebesar 5.305 pada $\mathrm{df}=110$ dengan nilai $\mathrm{t}$ tabel 1.98. Besarnya nilai $\mathrm{t}$ hitung $>\mathrm{t}$ tabel mengindikasikan bahwa pengaruhnya berdampak positif dan signifikan. Artinya bahwa 
ada pengaruh antara variabel pendidikan dan pelatihan terhadap kinerja karyawan di Citibank, sehingga sesuai dengan hipotesis Ho ditolak dan Ha diterima (diduga terdapat pengaruh positif dan signifikan antara pendidikan dan pelatihan terhadap kinerja karyawan di Citibank).

Hasil penelitian ini sependapat dengan teori Iwan Dermawan tahun 2014 tentang pengaruh pendidikan dan pelatihan terhadap kinerja karyawan pada Pusat Teknologi Informasi dan Komunikasi Pendidikan, Kementerian Pendidikan dan Kebudayaan bahwa pendidikan dan pelatihan mempunyai pengaruh positif dan signifikan terhadap kinerja karyawan. Jadi dari hasil penelitian tersebut, penulis menguatkan teori yang telah dikemukakan di atas.

2. Pengaruh Motivasi terhadap Kinerja Karyawan

Hasil pengujian pengaruh Motivasi terhadap kinerja karyawan secara statistik menunjukkan hasil yang positif dan signifikan. Hal itu ditunjukkan oleh nilai t hitung sebesar 9.913 pada $\mathrm{df}=110$ dengan nilai $\mathrm{t}$ tabel 1.98 . Besarnya nilai $t$ hitung $>t$ tabel mengindikasikan bahwa pengaruhnya berdampak positif dan signifikan. Artinya bahwa ada pengaruh antara variabel motivasi terhadap kinerja karyawan di Citibank, sehingga sesuai dengan hipotesis Ho ditolak dan Ha diterima (diduga terdapat pengaruh positif dan signifikan antara motivasi terhadap kinerja karyawan di Citibank).

Hasil penelitian ini sependapat dengan teori Heri Murtiyoko tahun 2014 tentang pengaruh motivasi terhadap kinerja karyawan di PT. Lautan Otsuka Chemical bahwa motivasi mempunyai pengaruh positif dan signifikan terhadap kinerja karyawan. Jadi dari hasil penelitian tersebut, sejalan teori yang telah dikemukakan di atas.

3. Pengaruh Kompensasi terhadap Kinerja Karyawan

Hasil pengujian pengaruh kompensasi terhadap kinerja karyawan secara statistik menunjukkan hasil yang positif dan signifikan. Hal itu ditunjukkan oleh nilai t hitung sebesar 2.610 pada df $=110$ dengan nilai $\mathrm{t}$ tabel 1.98 . Besarnya nilai $t$ hitung $>t$ tabel mengindikasikan bahwa pengaruhnya berdampak positif dan signifikan. Artinya bahwa ada pengaruh antara variabel kompensasi terhadap kinerja karyawan di Citibank, sehingga sesuai dengan hipotesis Ho ditolak dan Ha diterima (diduga terdapat pengaruh positif dan signifikan antara kompensasi terhadap kinerja karyawan di Citibank).

Hasil penelitian ini sependapat dengan teori Laura Komala tahun 2014 tentang pengaruh kompensasi terhadap kinerja karyawan pada PT. Bina Asia Tangerang bahwa kompensasi mempunyai pengaruh positif dan signifikan 
terhadap kinerja karyawan. Jadi dari hasil penelitian tersebut, penulis membenarkan teori yang telah dikemukakan di atas.

4. Pengaruh Pendidikan dan Pelatihan, Motivasi, dan Kompensasi terhadap Kinerja Karyawan

Hasil pengujian pengaruh Pendidikan dan pelatihan dan motivasi secara bersama-sama terhadap kinerja karyawan secara statistik menunjukkan hasil yang positif dan signifikan. Hal ini ditunjukkan oleh nilai $\mathrm{F}$ hitung sebesar 42.716 dengan $\mathrm{F}$ tabel adalah 2,69 . Besarnya nilai $F$ hitung > $\mathrm{F}$ table mengindikasikan bahwa pengaruhnya berdampak positif dan signifikan. Dengan demikian hipotesis yang menyatakan bahwa pengaruh Pendidikan dan pelatihan, motivasi dan kompensasi secara bersama-sama berpengaruh positif dan signifikan terhadap kinerja karyawan terbukti.

Hasil penelitian ini sesuai dengan teori Lia Fauziah tahun 2013 tentang pengaruh motivasi, pelatihan dan kompensasi terhadap kinerja karyawan pada PT. Nadira Prima Semarang bahwa motivasi, pelatihan dan kompensasi mempunyai pengaruh positif dan signifikan terhadap kinerja karyawan. Jadi dari hasil penelitian tersebut, penulis menguatkan teori yang telah dikemukakan di atas.

\section{PENUTUP}

\section{Kesimpulan}

Dari hasil pengujian hipotesa dan analisa pada bab terdahulu dapat diambil kesimpulan sebagai berikut:
1. Pengaruh Pendidikan dan Pelatihan terhadap Kinerja Karyawan.

Hasil pengujian pengaruh Pendidikan dan pelatihan terhadap kinerja karyawan secara statistik menunjukkan hasil yang positif dan signifikan. Hal itu ditunjukkan oleh nilai $\mathrm{t}$ hitung sebesar 5.305 pada df $=110$ dengan nilai $t$ tabel 1.98 . Besarnya nilai t hitung $>\mathrm{t}$ tabel mengindikasikan bahwa pengaruhnya berdampak positif dan signifikan.

2. Pengaruh Motivasi terhadap Kinerja Karyawan.

Hasil pengujian pengaruh Motivasi terhadap kinerja karyawan secara statistik menunjukkan hasil yang positif dan signifikan. Hal itu ditunjukkan oleh nilai $t$ hitung sebesar 9.913 pada df $=110$ dengan nilai $\mathrm{t}$ tabel 1.98. Besarnya nilai t hitung $>\mathrm{t}$ tabel mengindikasikan bahwa pengaruhnya berdampak positif dan signifikan.

3. Pengaruh Kompensasi terhadap Kinerja Karyawan.

Hasil pengujian pengaruh kompensasi terhadap kinerja karyawan secara statistik menunjukkan hasil yang positif dan signifikan. Hal itu ditunjukkan oleh nilai $t$ hitung sebesar 2.610 pada df $=110$ dengan nilai $\mathrm{t}$ tabel 1.98. Besarnya nilai t hitung 
$>\mathrm{t}$ tabel mengindikasikan bahwa pengaruhnya berdampak positif dan signifikan.

4. Pengaruh Pendidikan dan Pelatihan, Motivasi dan Kompensasi secara bersamasama terhadap Kinerja Karyawan.

Hasil pengujian pengaruh Pendidikan dan pelatihan, motivasi dan kompensasi secara bersama-sama terhadap kinerja karyawan secara statistik menunjukkan hasil yang positif dan signifikan. Hal ini ditunjukkan oleh nilai F hitung sebesar 42.716 dengan $\mathrm{F}$ tabel adalah 2,69. Besarnya nilai $\mathrm{F}$ hitung $>\mathrm{F}$ table mengindikasikan bahwa pengaruhnya berdampak positif dan signifikan. Dengan demikian hipotesis yang menyatakan bahwa pengaruh Pendidikan dan pelatihan dan motivasi secara bersama-sama berpengaruh positif dan signifikan terhadap kinerja karyawan terbukti.

\section{Saran}

Selanjutnya, adapun saransaran sebagai pelengkap terhadap hasil penelitian ini adalah sebagai berikut:

a. Hasil yang dicapai dalam penelitian ini menunjukkan bahwa pengaruh pendidikan dan pelatihan sebesar $15.1 \%$, motivasi sebesar 28.7\%dan kompensasi sebesar $4.9 \%$ terhadap kinerja karyawan sedangkan sisanya $51.3 \%$ dipengaruhi oleh variabel lain. b. Diharapkan untuk penelitian selanjutnya ditambahkan variabel lain sehingga hasil yang berpengaruh terhadap kinerja lebih maksimal baik dalam hal peningkatan kuantitas maupun kualitas karyawan di perusahaa

\section{Daftar Pustaka}

Undang-Undang Nomor 20 Tahun 2003 Tentang Sistem Pendidikan Nasional

Undang-Undang Nomor 13 Tahun 2003

Tentang

Ketenagakerjaan

Bangun, Wilson. 2012. Manajemen Sumber Daya Manusia. Erlangga. Jakarta

Dessler, Gary. 2009. Manajemen Sumber Daya Manusia. Indeks. Jakarta

Fahmi, Irham. 2010. Manajemen Kinerja (Teori dan Aplikasi). Alfabeta. Bandung

Fitri, Yunita Sari. 2010. Manajemen Personalia dan Sumber Daya Manusia Perusahaan. BPFE. Yogyakarta

Handoko, T. Hani. 2010. Manajemen Personalia dan Sumber Daya Manusia (Edisi 2). BPFEYogyakarta Anggota IKAPI. Yogyakarta

Hariandja, Marihot Tua Efendi. 2002. Manajemen Sumber Daya Manusia. Grasindo. Jakarta

Hasibuan, Malayu S.P. 2001. Manajemen Sumber Daya Manusia. Bumi Aksara. Jakarta

Hasibuan, Malayu S.P. 2006. Manajemen Sumber Daya Manusia. Edisi Revisi Bumi Aksara. Jakarta

Hastho, Seko Nur Utomo dan Meilan Susanto. 2007. Manajemen 
Sumber Daya Manusia.

Ardana Media. Yogyakarta.

Mangkunegara, A.A. Anwar Prabu.

2000. Manajemen Sumber

Daya Manusia. PT Remaja

Rosda Karya.Bandung

Mangkunegara, A.A. Anwar Prabu. 2006. Evaluasi Kinerja Sumber Daya Manusia. Refika Aditama. Jakarta

Notoatmodjo, Soekidjo. 2003. Pendidikan dan Perilaku Kesehatan. Rineka Cipta. Jakarta

Notoatmodjo, Soekidjo. 2009. Pengembangan Sumber Daya Manusia. Rineka Cipta. Jakarta

Pusat Bahasa Departemen Pendidikan Nasional. 2002.

Kamus Besar Bahasa Indonesia. Balai Pustaka. Jakarta

Riduwan dan Engkos Achmad Kuncoro. 2012. Cara Mudah Menggunakan dan Memaknai Path Analysis (Analisis Jalur) Lengkap dengan Contoh Tesis dan Perhitungan SPSS 17.0. Alfabeta. Bandung
Rivai, Veithzal. 2004. Manajemen Sumber Daya Manusia Teori dan Praktik. Raja Grafindo Persada. Jakarta

Robbins, Stephen P. 2006. Perilaku Organisasi. PT Indeks Kelompok Gramedia. Jakarta

Robbert, L. Mathis. 2007. Human Resources Management (Edisi Sepuluh). Salemba. Jakarta

Sedarmayanti. 2009. Sumber Daya Manusia dan Produktivitas Kerja. Mandar Maju. Bandung

Sedarmayanti. 2013. Manajemen Sumber Daya Manusia, Reformasi Birokrasi, dan Manajemen Pegawai Negeri Sipil. Refika Aditama. Bandung

Setiawan, Toni. 2012. Manajemen Sumber Daya Manusia : Kinerja, Motivasi, Kepuasan Kerja dan Produktivitas. Platinum. Jakarta

Solihin, Ismail. 2009. Pengantar Manajemen. Erlangga. Jakarta

Sugiyono. 2013. Metode Penelitian Kombinasi (Mixed Methods). Alfabeta. Bandung 